\title{
Dietary exposure to selected chemical contaminants in fish for the Danish population
}

Duedahl-Olesen, Lene; Cederberg, Tommy Licht; Christensen, Tue; Fagt, Sisse; Fromberg, Arvid; Granby, Kit; Hansen, Max; Boberg, Julie; Sloth, Jens Jørgen; Petersen, Annette

Published in:

Food Additives \& Contaminants: Part A - Chemistry, Analysis, Control, Exposure \& Risk Assessment

Link to article, DOI:

$10.1080 / 19440049.2020 .1743374$

Publication date:

2020

Document Version

Peer reviewed version

Link back to DTU Orbit

Citation (APA):

Duedahl-Olesen, L., Cederberg, T. L., Christensen, T., Fagt, S., Fromberg, A., Granby, K., Hansen, M., Boberg, J., Sloth, J. J., \& Petersen, A. (2020). Dietary exposure to selected chemical contaminants in fish for the Danish population. Food Additives \& Contaminants: Part A - Chemistry, Analysis, Control, Exposure \& Risk Assessment, 37(6), 1027-1039. https://doi.org/10.1080/19440049.2020.1743374

\section{General rights}

Copyright and moral rights for the publications made accessible in the public portal are retained by the authors and/or other copyright owners and it is a condition of accessing publications that users recognise and abide by the legal requirements associated with these rights.

- Users may download and print one copy of any publication from the public portal for the purpose of private study or research.

- You may not further distribute the material or use it for any profit-making activity or commercial gain

- You may freely distribute the URL identifying the publication in the public portal 


\section{Food Additives}

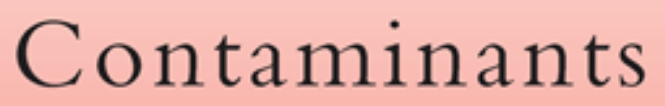

PART A:

CHEMISTRY • ANALYSIS • CONTROL • EXPOSURE \& RISK ASSESSMENT

\section{Dietary exposure to selected chemical contaminants in fish for the Danish population}

\begin{tabular}{|r|l|}
\hline Journal: & Food Additives and Contaminants \\
\hline Manuscript ID & TFAC-2019-506.R1 \\
\hline Manuscript Type: & Original Article \\
\hline Date Submitted by the & n/a \\
\hline Complete List of Authors: & $\begin{array}{l}\text { Duedahl-Olesen, Lene; Technical University of Denmark, National Food } \\
\text { Institute } \\
\text { Cederberg, Tommy; Technical University of Denmark, National Food } \\
\text { Institute } \\
\text { Christensen, Tue; Technical University of Denmark, National Food } \\
\text { Institute } \\
\text { Fagt, Sisse; Technical University of Denmark, National Food Institute } \\
\text { Fromberg, Arvid; Technical University of Denmark, National Food } \\
\text { Institute } \\
\text { Granby, Kit; Technical University of Denmark, National Food Institute ; } \\
\text { Hansen, Max; Technical University of Denmark, National Food Institute } \\
\text { Boberg, Julie; Technical University of Denmark, National Food Institute }\end{array}$ \\
\hline
\end{tabular}




\begin{tabular}{|c|c|}
\hline & $\begin{array}{l}\text { Sloth, Jens; Technical University of Denmark, National Food Instirute } \\
\text { Petersen, Annette; Technical University of Denmark, National Food } \\
\text { Institute }\end{array}$ \\
\hline Methods/Techniques: & $\begin{array}{l}\text { Metals analysis - ICP/MS, Chromatography - GC/MS, Chromatography - } \\
\text { LC/MS, Exposure }\end{array}$ \\
\hline Additives/Contaminants: & $\begin{array}{l}\text { Heavy metals - mercury, Environmental contaminants, Process } \\
\text { contaminants - PAH's }\end{array}$ \\
\hline Food Types: & Fish and fish products \\
\hline Abstract: & $\begin{array}{l}\text { The exposure to selected chemical contaminants from fish has been } \\
\text { calculated for the Danish population, both for adults ( } 15-75 \text { years of } \\
\text { age) and children ( } 4-14 \text { years of age). The Danish mean consumption of } \\
\text { fish is } 21 \mathrm{~g} \text { person }^{-1} \text { day }^{-1} \text { for adults and } 12 \mathrm{~g}^{-1} \text { person }{ }^{-1} \text { day }^{-1} \text { for } \\
\text { children. Fish consumption is the main food group contributor for } \\
\text { exposure to mercury and dioxins and dioxin-like polychlorinated } \\
\text { biphenyls (PCDD/F and DL-PCB) for the Danish population. Comparison } \\
\text { of the mean exposure with the TDI or TWI values show for these } \\
\text { substances as well as for perfluorooctane sulphuric acid (PFOS) that the } \\
\text { exposure is below the TDI/TWI values. However, even without taking } \\
\text { other food groups into account, PCDD/Fs and DL-PCB exposure is close } \\
\text { to the actual TWI-value. Calculation of the Margin of Exposure (MOE) for } \\
\text { the sum of hexabromocyclododecanes (HBCDD) and polycyclic aromatic } \\
\text { hydrocarbons (PAHs) revealed fish consumption to be of low concern for } \\
\text { the consumer health regarding these contaminants. }\end{array}$ \\
\hline
\end{tabular}

\section{SCHOLARONE ${ }^{\text {m }}$ Manuscripts}




\title{
Dietary exposure to selected chemical contaminants in fish for the Danish population
}

\author{
Lene Duedahl-Olesen, * T.L. Cederberg, T. Christensen, S. Fagt, A. \\ Fromberg, K. Granby, M. Hansen, J. Boberg, J.J. Sloth and A. Petersen \\ National Food Institute, Technical University of Denmark, 2800 Kongens Lyngby, \\ Denmark
}

*Corresponding author: Lene Duedahl-Olesen (ORCiD: 0000-0002-3162-0101), National Food Institute, Technical University of Denmark, Kemitorvet, Building 201, DK-2800 Kongens Lyngby, lduo@ffood.dtu.dk

Cederberg, Tommy Licht. National Food Institute, Technical University of Denmark, Kemitorvet, Building 201, DK-2800 Kongens Lyngby.

Christensen, Tue. National Food Institute, Technical University of Denmark, Kemitorvet, Building 201, DK-2800 Kongens Lyngby.

Fagt, Sisse. National Food Institute, Technical University of Denmark, Kemitorvet, Building 201, DK-2800 Kongens Lyngby.

Fromberg, Arvid. National Food Institute, Technical University of Denmark, Kemitorvet, Building 201, DK-2800 Kongens Lyngby.

Granby, Kit. National Food Institute, Technical University of Denmark, Kemitorvet, Building 201, DK-2800 Kongens Lyngby.

Hansen, Max. National Food Institute, Technical University of Denmark, Kemitorvet, Building 201, DK-2800 Kongens Lyngby.

Boberg, Julie. National Food Institute, Technical University of Denmark, Kemitorvet, Building 202, DK-2800 Kongens Lyngby.

Sloth, Jens Jørgen. National Food Institute, Technical University of Denmark, Kemitorvet, Building 201, DK-2800 Kongens Lyngby.

Petersen, Annette. National Food Institute, Technical University of Denmark, Kemitorvet, Building 201, DK-2800 Kongens Lyngby. 


\title{
Dietary exposure to selected chemical contaminants in fish for the Danish population
}

\begin{abstract}
The exposure to selected chemical contaminants from fish has been calculated for the Danish population, both for adults (15-75 years of age) and children (4-14 years of age). The Danish mean consumption of fish is $21 \mathrm{~g} \mathrm{person}^{-1}$ day $^{-1}$ for adults and $12 \mathrm{~g} \mathrm{person}^{-1} \mathrm{day}^{-1}$ for children. Fish consumption is the main food group contributor for exposure to mercury and dioxins and dioxin-like polychlorinated biphenyls (PCDD/F and DL-PCB) for the Danish population. Comparison of the mean exposure with the TDI or TWI values show for these substances as well as for perfluorooctane sulphuric acid (PFOS) that the exposure is below the TDI/TWI values. However, even without taking other food groups into account, PCDD/Fs and DL-PCB exposure is close to the actual TWI-value. Calculation of the Margin of Exposure (MOE) for the sum of hexabromocyclododecanes (HBCDD) and polycyclic aromatic hydrocarbons (PAHs) revealed fish consumption to be of low concern for the consumer health regarding these contaminants.
\end{abstract}

Keywords: PCDD/F and DL-PCB, PAH4, Mercury, PFOS, sum of HBCDD, Margin of Exposure (MOE), Health Based Guidance Values (HBGV)

\section{Introduction}

Fish consumption is generally considered an important source of essential compounds such as selenium, iodine, vitamin D and essential fatty acids (DVFA 2018). Therefore, authorities in several countries have published recommendations for fish consumption. The Danish Veterinary and Food Administration (DVFA) recommend consumption of at least two main meals of fish and fish for lunch several times per week corresponding to 350 gram fish per week for adults and 260 gram for children (DVFA 2018, Christensen LM 2016 personal communication provided unpublished fish consumption 
for children, unreferenced). For adults 200 gram per week should be fatty fish. The Danish recommendations are in line with the American Heart Association recommendation on consumption of at least two meals of fish per week (Krauss et al. 2000).

At the same time, it is well known that fish can be one of the major a major exposure routes for e.g. mercury trace metals-and persistent organic pollutants (POPs). in humans mainly due to bioaccumulation abilities of the compounds. The levels of contaminants in fish depend on the type of fish and their fat content for fat soluble contaminants (Fromberg et al. 2011), the area where the fish live (DVFA 2005; Petersen et al. 2013; Sørensen et al. 2016), the age of the fish and the processing method (Cederberg et al. 2010; Duedahl-Olesen et al. 2010). An example of this is that salmon from the Baltic Sea has considerably higher amounts of dioxins and dioxin-like polychlorinated biphenyls (PCDD/F and DL-PCB) than salmon from the Atlantic Sea (Sørensen et al. 2016) and that some fish placed high in the aquatic food-chain such as tuna and halibut can contain high concentrations of mercury. On this background the Danish authorities also have specific advises for the consumption of some kind of fish for specific consumer groups, e.g. pregnant women, women of child-bearing age and children.

Food monitoring programs for foods on the Danish market has been reported for five year periods from 1983 to 2003 (NFA 1990, 1995; DVFA 2001, 2005) and The longest most recent period report comprise a period of 8 years (2004 to 2011, Petersen et al. 2013). In all these reports monitoring data were included as well as exposure assessment for e.g. environmental contaminants, processing contaminants and some elements. In Petersen et al. 2015, monitoring data for the period 2012-2013 were included. 
In the present study the exposure to contaminants from consumption of fish from the Danish market was calculated for the adult Danish population (15-75 years of age) as well as Danish children (4-14 years of age). The exposure was also estimated, for Fish eaters, which were defined as people eating fish no matter the amount during the registration period of seven days of the Danish food consumption survey. The calculated exposures were compared to Health Based Guidance Values (HBGVs) published by EFSA or the calculated Margin of Exposure (MOE) based on benchmark dose levels (BMDL) from EFSA.

The substances included in this study are one element as well as some environmental and process contaminants. The element included in this study is mercury $(\mathrm{Hg})$ that in the aquatic environment can form methyl-mercury $(\mathrm{Me}-\mathrm{Hg})$, which is the most toxic species of mercury. The exposure to Me-Hg is assessed on the background of analysis of $\mathrm{Hg}$ in fish. The environmental contaminants include PCDD/F and DL-PCB, PCB-6, the brominated flame retardant HBCDD (hexabromocyclododecane), the perfluorinated compound PFOS (perfluorooctane sulphuric acid) and PAHs (polycyclic aromatic hydrocarbons). PCB-6 is used as an abbreviation for the sum of six indicator congeners for non-dioxin like PCBs, namely PCB-28, 52, 101, 138, 153 and 180. For PAHs the sum of four PAHs compounds are reported in this study and is denoted PAH4. PAHs are both environmental and process contaminants and can be formed during grilling and smoking of fish.

\section{Materials and methods}

\section{Samples and sample preparation}

Samples of fish from Danish waters were taken by the Fisheries Inspection under the Danish Directorate of Fisheries. Market fish samples were taken by authorised 
personnel from the regional authorities at DVFA in various parts of Denmark. Samples were collected over the years 2004 to $201 \underline{3}$. Yearly monitoring plans were the basis for random sampling in compliance with EC Regulation No. 333/2007 (EC 2007) for trace elements, PAHs, PCDD/F and PCB while farmed fish sampling followed EU directive 96/23/EC (EC 1996) for PCDD/F and PCB. If known, it is specified if the fish are wild or from aquaculture. Fish skin and bones were removed prior to analysis and the remaining fish muscle was stored at $-18^{\circ} \mathrm{C}$ until analysis. It was assumed that very few people eat the fish skin and that the migration of the substances from the skin to the rest of the fish during preparation was negligible. Heat treated glassware and selected utensils (e.g. metal-free utensils) were used to reduce the risks of background contamination from the laboratory equipment.

\section{Analysis of contaminants}

The analytical work was carried out at the regional laboratories of the DVFA, unless otherwise stated. All analyses were performed with accredited methods in accordance with EN 45000 or ISO17025. External calibration with isotopic labelled compounds or internal standardisation was used for quantification. Various procedures for quality assessment of the analysis were carried out including criteria for tolerable variations of blank samples, recovery tests (70-110\%), use of certified reference materials (CRMs), $\mathrm{X}$-charts and participation in proficiency tests and analysis of doublets (R-charts). According to International Union on Pure and Applied Chemistry (IUPAC 2010) the limit of detection (LOD) of an analytical procedure is the lowest amount of the actual analyte in the sample that can be positively detected. The limit of quantitation (LOQ) is defined as the lowest concentration at which an unambiguous identification and quantification of the analyte can be proven. The Performance criteria in EC Regulation 
No. 333/2007 (EC 2007) were followed for the analysis of mercury and PAH whereas similar requirements for PCDD/F and DL-PCB analysis stated in the EU legislation were followed (EC 2002; EC 2006b). This includes criteria for LOD with LOD $<0.1$ $\mu \mathrm{g} / \mathrm{kg}$ wet weight and $0.3 \mu \mathrm{g} / \mathrm{kg}$ wet weight for mercury and each of PAH4, respectively (EC 2007). For PCDD/F and DL-PCB criteria for LOD was obtained fulfilling the requirements stated for Upper bound and lower bound concentrations (EC 2002, EC 2006b). For details of specific analytical methods we refer to literature under the relevant sections.

\section{Mercury.}

For the determination of the total level of mercury $(\mathrm{Hg})$, representative subsamples of the homogenised food samples were digested by microwave-assisted wet-ashing in quartz vessels with concentrated nitric acid. The mercury concentration was then determined by inductively coupled plasma-mass spectrometry (ICP-MS) (Larsen et al. 2007). LODs were estimated from the variance of the procedural blank values.

$P C D D / F$ and $D L-P C B$ and $P C B-6$.

In 2004, the National Food Institute, Technical University of Denmark analysed samples of fish, fish oils and mussels, all other samples were analysed by DVFA as described above. Congeners specific determination was achieved for the seven 2,3,7,8chloro substituted PCDDs, the ten 2,3,7,8-chloro substituted PCDFs, the four non-ortho PCB (PCB77, 81, 126 and 169) and eight mono-ortho PCB (PCB105, 114, 118, 123, 156, 157, 167 and 189) denoted as PCDD/F and DL-PCB with additional six PCBs (PCB28, PCB52, PCB101, PCB138, PCB153 and PCB180) denoted as PCB-6. After fat extraction by Soxhlet or accelerated solvent extraction, the fat was cleaned up on a multi-layer column and separated into two fractions (a) PCDD/F and non-ortho PCB 
and (b) di- and mono-ortho PCB. The instrumental detection and quantification was carried out by GC-HRMS at a mass resolution of 10,000 as described by Cederberg and co-workers (Cederberg et al. 2010).

\section{Perfluorinated compounds (PFAS).}

Only sampling in 2011 was included with fish collected from Danish catching areas in the Baltic Sea and the North Sea. Additional eight samples from aquaculture produce were collected: four from freshwater farms, and four from marine farms. Per-fluorinated compounds were analysed in filets in pools of three to ten fish from the same age group except for samples of larger fish as they were analysed as individual fish. The analysis focused on perfluorooctanoic acid (PFOA) and perfluorooctane sulphonic acid (PFOS). Solid phase extraction followed by LC-MS/MS detection were used and performed as described by Rasmussen et al. 2017. Both PFOA and PFOS were analysed in fish, but PFOA was not found in levels above LOD of $0.5 \mathrm{ng} \mathrm{g}^{-1}$ wet weight and therefore the exposure have not been calculated.

\section{Brominated Flame Retardants (BFR).}

Analysis was carried out at the National Food Institute on selected fish samples collected from Danish catching areas in the Baltic Sea and the North Sea 2002, 2003 and 2006, as well as from fish farms. The method was validated for all the analysed substances (Aznar-Alemany et al., 2017). All samples were previously analysed for PCDD/F+DL-PCB (see above). Evaporated Soxhlet extracts were dissolved in internal standard solution, cleaned up and analysed for three isomers of hexabromocyclododecane (HBCDD) namely $\alpha-, \beta-$, and $\gamma$-HBCDD as well as tetrabromobisphenol A (TBBPA) using a Kinetex C-18 column with LC-MS/MS (Granby and Cederberg 2007). Only one sample of farmed salmon contained TBBPA 
above LOD and therefore the exposure was not calculated in this study. For the isomers of HBCDD the LOD were $0.01 \mathrm{ng} / \mathrm{g}$ wet weight for each isomer (Petersen et al., 2013).

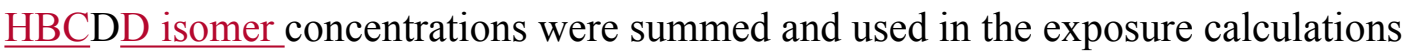

PAH4.

A total of 25 PAHs in 206 fish samples, raw and smoked were included from 2006 to 2011. Analysis included pressurised liquid extraction followed by gel permeation chromatography (GPC) and solid phase extraction (SPE) for clean-up before GC-MS analysis on a 50m DB-5 MS capillary column as described by Duedahl-Olesen et al. (2010). The sum of PAH4 including the sum of actual values for benzo[a]pyrene, benz $[a]$ anthracene, chrysene and benzo $[b]$ fluoranthene (estimated as $1 / 2$ benzo $[b+j]$ fluoranthene) is reported.

\section{Concentration data for the exposure assessment}

The data for the contaminant concentrations were from the two periods 20042011 and 2012-2013 (Petersen et al., 2013, 2015). -For PCDD/F and DL-PCB and PCB$\underline{6 \text { data for the period 2014-2016 have been included (Petersen et al., 2013, 2015; DVFA, }}$ 2020) 1, except for PCDD/F and DL PCB and PCB-6 where data from 2012 and 2013 were included.

Not all contaminants have been analysed in all fish species and for some species results were read-across from one fish species to another. For example the missing concentration of PCDD/F and DL-PCB in canned cod roe were set to the concentration of Greenland Halibut (see Table 1). This read-across was performed on a case-to-case basis and in general, if the concentrations were similar for a combination of fish and contaminants, read-across were applied. In the exposure assessment mean values for the 
actual contaminant in the fish product were used. For HBCDD andPAH4 values below LOD were included as having a concentration of zero similar to lower bound approaches presented by EFSA (EFSA 2008). For Hg and HBCDD all measured values, including values below LOD were used considering the use of the value of zero as an under estimation of the actual concentration. For PCDD/F and DL-PCB, all values below LOD were substituted with the actual LOD (in WHO-TEQ) (EFSA 2018a). For PFAS the LOD of $0.5 \mathrm{ng} \mathrm{g}^{-1}$ were used for non-detected samples. Using the LOD for each non-detected contaminant would however lead to an overestimation of the exposure. On the other hand it is known to be an under-estimation to do the assumption that all samples with concentrations below LOD do not have any content of the contaminant. Concentrations between LOQ and LOD was given as measured values. The mean concentrations used in the exposure calculations are shown in Table $1 \underline{\text { with }}$ $\underline{\text { additional information on sample numbers, maximum and minimum values in }}$ supplementary material (S1-S6).

\section{Dietary Consumption}

The data on food consumption of individual types of fish were collected as a part of DANSDA (DAnish National Survey of Diet and physical Activity) in 2005-2008 and are a subset of the data reported in 'Dietary Habits in Denmark 2003-08' (Pedersen et al. 2010). The subset was chosen because it matches the period for chemical analysis best. The dataset covers consumption of food and beverages recorded for 7 consecutive days collected from a representative group of 2700 Danes aged 4 to 75 years. The individuals were drawn as a simple random sample from the civil population registration system. DANSDA used a 7-day pre-coded (semi-closed) food diary with answering categories for the most commonly consumed foods and dishes in the Danish diet. The questionnaire was organised in accordance with the typical daily meal pattern. 
For food items not found in the pre-coded categories, it was possible to note the type and amount eaten. The amounts of food consumed were based on photos of various portion sizes. The information collected represents the current dietary consumption in the population. The Danish National Centre for Social Research carried out the interviews and the instruction of participants in the registration of the dietary consumption. The self-reported bodyweight of the individual respondents was used in those cases where the results of the exposure calculation are stated as exposure per $\mathrm{kg}$ bodyweight.

Dietary records were processed in-house by scanning with ReadSoft Forms and followed by storing and post scan processing in an in-house relational database management system (Scan 2005). The consumption data were then processed by the inhouse-developed GIES (General Exposure Estimation System) that interpret the recorded consumption into the ingredients that form the basis for the calculations and estimations of the intake of contaminants (Christensen 2001). To align the interpretation of registered fish intake with the actual market, data over purchased foods from consumer panels (GfK 2019) were used to make the fish recipes.

\section{Exposure}

The mean chronic exposure to each of the contaminants was estimated by multiplying the mean concentration (Table 1) with the mean consumption for the individual fish species and consumer group (Table 2) divided with the self-reported average bodyweight of the respectively consumer groups, $74 \mathrm{~kg}$ for adults (15-75 years of age) and $36 \mathrm{~kg}$ for children (4-14 years of age).

$$
\text { Exposure } \left._{\mathrm{i}}=\text { Concentration }_{\mathrm{i}} \mathrm{x}\left(\text { Consumption }_{\mathrm{i}}\right) \mathrm{bw}^{-1}\right)
$$

$$
\text { where } \mathrm{i}=\text { fish species }
$$

Total exposure $_{\text {fish }}=\Sigma$ Exposure $_{\mathrm{i}}$ and bw $=$ body weight 
The exposure was estimated for the 2133 adults and 567 children included in the Danish dietary survey, (All, see Table 2). The exposure was also estimated for the subgroup of Fish eaters. Furthermore, exposure was estimated for the consumers of individual fish species, e.g. the exposure estimate for the 710 adults that eat cod filet (see Table 2) and this consumer group is denoted Fish eaters only (see Table 2). For All and Fish eaters the consumptions were added to give an estimate of the total exposure from fish. The total exposure was also estimated for lean and fatty fish, respectively defining lean fish as having a fat content below $5 \%$ on wet weight basis (cod, garfish, halibut, saithe, plaice and trout) and fatty fish as having a fat content above 5\%. Finally, an exposure scenario for consumers complying with the Danish dietary guidelines on fish consumption, was set up. This scenario was calculated using the ratio between the recommended consumption (e.g. $50 \mathrm{~g} \mathrm{day}^{-1}$ for adults and $37 \mathrm{~g} \mathrm{day}^{-1}$ for children) and the current consumption of fish species for all adults and children, respectively. This scenario can be considered as a high consumer scenario compared to the current mean consumption of fish.

\section{Assessment of the exposure}

For estimation of a potential risk, either the Hazard Quotient (HQ) or the Margin of Exposure (MOE) has been calculated. HQs were estimated as the ratio between the total exposure and the health based guidance value (HBGV) and for HQs $<1$ exposure was evaluated to be of low consumer concern. MOEs were estimated, as the benchmark dose lower confidence limit for the chosen benchmark response of an effect, e.g. of $10 \%$ $\left(\mathrm{BMDL}_{10}\right)$ divided by the exposure from consumption of the actual contaminant (EFSA 2005). For genotoxic and carcinogenic substances a MOE of 10.000 or higher is considered to be of low concern from a public health point of view (EFSA, 2005). For all other substances no fixed values are recommended and the appropriate MOE has to 
be decided on a case-by-case situation.

\section{Results and Discussion}

\section{Dietary consumption of fish}

Dietary consumption of individual fish species and fish products for adults and children are shown in Table 2 for all consumers, consumers of fish termed Fish eaters as well as for consumers eating that specific fish (Fish eaters only). Fish eaters are, as explained previously, all participants who have indicated to have consumed any amount of fish during the diary period. As seen in Table 2, higher consumption of fish is obtained for Fish eaters with $91 \%$ adults and $82 \%$ children consuming fish during the 7 -day dietary consumption survey. For adults (aged 15-75 y) and for adult Fish eaters the average consumption is 21 and $23 \mathrm{~g}$ day $^{-1}$, respectively and corresponds to less than half of the recommended consumption of $50 \mathrm{~g}$ fish per day (DVFA 2018). Also for children (aged 4-14 y) the consumption is lower than the recommended average of $37.1 \mathrm{~g} \mathrm{day}^{-1}$ for the age group of 10 years (Christensen 2016, personal communication provided unpublished children consumption of fish data) with an average consumption of $12.4 \mathrm{~g}$ day $^{-1}$ and a Fish eater consumption of $15.1 \mathrm{~g} \mathrm{day}^{-1}$. None of the consumer groups follow the recommended distribution of fatty fish of $28.6 \mathrm{~g} \mathrm{day}^{-1}$ for adults and $21.2 \mathrm{~g} \mathrm{day}^{-1}$ for children. The consumption data in Table 2 show that the actual consumption of fatty fish corresponds to about $40 \%$ of the total consumption for adults and about $31 \%$ for children.

Based on the number of consumers, the most popular fish species for adults are canned mackerel in tomato sauce (1113 consumers), marinated herring (1106), frozen shrimps (1074) and smoked salmon (958) whereas for children canned tuna (246 consumers) is the most popular fish product followed by mackerel in tomato sauce 
(212), frozen shrimps (171) and smoked salmon/mackerel or eel (153) (see Table 2). The Danish culture with frequent eating of home-made lunch boxes at school and at work are probably reflected here with the high consumption rate of canned fish such as tuna and mackerel in tomato. In comparison, the highest amount of fish in gram per day consumed by all Danish adults are plaice $\left(3.2 \mathrm{~g} \mathrm{day}^{-1}\right)$ followed by cod $\left(3.15 \mathrm{~g} \mathrm{day}^{-1}\right)$ and raw salmon (2.94 $\left.\mathrm{g} \mathrm{day}^{-1}\right)$ whereas for children highest amounts of plaice $(2.5 \mathrm{~g}$ day $\left.^{-1}\right)$ are consumed followed by canned tuna $\left(2.4 \mathrm{~g} \mathrm{day}^{-1}\right)$ and raw salmon $\left(1.5 \mathrm{~g} \mathrm{day}^{-1}\right)$ (see Table 2). Except for canned tuna these fish species are commonly consumed as a hot meal e.g. dinners in Denmark and therefore the higher consumption of these is a reflection of the higher consumption per meal in the evening compared to lunch. In comparison, adults in Denmark have less than half the daily consumption of fish compared to Spain (51 $\left.\mathrm{g} \mathrm{day}^{-1}\right)$ (Llobet et al. 2006) and Korea (50.6 $\left.\mathrm{g} \mathrm{day}^{-1}\right)$ (Moon et al. 2010). Also children in Catalonia eat twice the amount of fish compared to Danish children (Marti-Cid et al. 2007).

\section{Mercury}

Mercury $(\mathrm{Hg})$ naturally present in the Earth's crust, and has been used in various industrial applications (e.g. batteries, cabels, dental amalgams) and is formed in its various chemical forms by incineration of waste (Petersen et al. 2013). The total $\mathrm{Hg}$ exposure for the Danish population aged 4-75 years was estimated to be $0.018 \mu \mathrm{g} \mathrm{kgbw}{ }^{-}$ ${ }^{1}$ for the period 2004-2011 (Petersen et al. 2013). Fish are the main contributor to the dietary exposure of total mercury and contribute almost $68 \%$ of the total food exposure (Petersen et al. 2013) and all other food groups contribute less than 10\% each.

Diversified consumption of fish is relevant especially for children due to that some fish especially those high in the food-chain have high concentration levels. $\mathrm{Me}-\mathrm{Hg}$ is the mercury species where adverse effects is observed at the lowest dose and is the 
predominant chemical form of mercury found in fish. In this study, mercury in fish is considered to be Me-Hg, which may adversely affect the central nervous system particular during foetal development (EFSA 2012) and a tolerable weekly intake (TWI) of $1.3 \mu \mathrm{g} \mathrm{kgw}^{-1}$ has been established by EFSA. For assessment of the exposure of to $\mathrm{Me}-\mathrm{Hg}$ data for total mercury was used and a conversion factor of 1.0 was applied as described by EFSA in 2012.

Me-Hg exposure estimated in this study was lowest for all adults, (1622 $\mathrm{ng}$ $\mathrm{kgbw}^{-1}$ day $^{-1}$ ) and highest for Children, Fish eaters with $\underline{4429} \mathrm{ng} \mathrm{kgbw}^{-1}$ day $^{-1}$ (see Figure 1a). It is not possible to compare the $\mathrm{Hg}$ values from the report for 2004-2011 (Petersen et al. 2013) with the estimated Me-Hg exposure in this study due to differences in age groups. The Danish Me-Hg exposure from fish corresponds to the total Me-Hg exposure levels reported in the French adult population (17 $\mathrm{ng} \mathrm{kgbw}^{-1}$ day $^{-}$

1) (ANSES 2011a) but is slightly lower than the EFSA evaluation for Denmark (170 ng $\mathrm{kgbw}^{-1}$ week $^{-1}$ corresponding to $24 \mathrm{ng} \mathrm{kgbw}^{-1} \mathrm{day}^{-1}$ ) (EFSA 2012). The results in this study show that the HQ is less than $0.1 \underline{3} \theta$ for adults and 0.2316 for children (Table 3 ). Fish like sword fish and tuna high in the food chain can have high concentrations of Me-Hg due to bioaccumulation. That is one of the reasons that the Danish authorities have recommendations for consumption of these kind of fish.

\section{$P C D D / F$ and $D L-P C B$}

The most sensitive effects for PCDD/F and DL-PCB in animal studies have been on the reproductive, immune, and central nervous system (EFSA 2018a). Highest concentrations of PCDD/F and DL-PCB were obtained for cod liver (Petersen et al, 2013). These high levels reveal the compounds lipophilic properties and that they accumulate in the fatty tissues of animals and humans. The concentrations in fish also depend on catch areas and the importance of this areas were illustrated by higher 
concentrations of PCDD/F and DL-PCB in salmon, sprat and herring caught in the Baltic sea (Fromberg et al. 2011; Petersen et al. 2013; Sørensen et al. 2016; EFSA 2018a).

For PCDD/F and DL-PCB the mean total exposure for the period 2004-2011 (Petersen et al. 2013) was estimated to be respectively $0.55 \mathrm{pg}$ WHO-TEQ ${ }^{2005} \mathrm{kgbw}^{-1}$ day $^{-1}$ and $0.87 \mathrm{pg}$ WHO-TEQ $^{2005} \mathrm{kgbw}^{-1} \mathrm{day}^{-1}$ for the total population (aged 4-75) and children (aged 4-14). The estimated daily exposures from fish among fish eaters are 0.18 and $0.21 \mathrm{pg}$ WHO-TEQ ${ }^{2005} \mathrm{kgbw}^{-1} \mathrm{day}^{-1}$ for adults and children, respectively (see Figure $1 b)$. The exposure from fish amounts to about $25 \%$ of the total exposure for both consumer groups. For adults it is not possible to compare the estimated exposure from 2004-2011 (Petersen et al. 2013) with the estimated exposure in this study due to differences in age groups. In Petersen et al., 2013 fish was the food group that contribute most to the exposure (45\%) but also fat, meat, cheese and milk, and their derived products contributed with more than $10 \%$ to the exposure.

EFSA has in 2018 set a new lower TWI of 2 pg WHO-TEQ kgbw $^{-1}$ week $^{-1}$ or $0.29 \mathrm{pg} \mathrm{kgbw}^{-1} \mathrm{day}^{-1}$ which is a factor of 7 lower than the previous TWI (EFSA 2018a). The current TWI is based on epidemiological studies with semen quality as the critical effect (EFSA 2018a). As can be seen from Table 3 the TWI is not exceeded for adults or children but the consumption of fish alone amounts to more than half of the TWI. It also appears from Table 3 the HQ would be above 1 if the Danish population eat the recommended amount of fish and the distribution of the consumed fish was the same as the current distribution. This would mean that the TWI would be exceeded from the fish consumption alone for the average population if they were fulfilling the dietary guideline for fish consumption. 
For PCB-6 the mean total daily exposure for the whole diet for the period 20042011 was estimated to be $1.8 \mathrm{ng} \mathrm{kgbw}^{-1} \mathrm{day}^{-1}$ and $2.7 \mathrm{ng} \mathrm{kgbw}^{-1} \mathrm{day}^{-1}$ for children (aged 4-14) and total population (aged 4-75) (Petersen et al. 2013). The estimated daily exposure from fish is respectively $0.9 \mathrm{ng} \mathrm{kgbw}^{-1} \mathrm{day}^{-1}$ for children and $1.0 \mathrm{ng} \mathrm{kgbw}^{-1}$ day $^{-1}$ for adults (see Figure 1c), so for children the exposure from fish amounts to $56 \%$ of the total exposure. For PCB6 a TDI set by the French Food Safety Agency (AFSSA) in 2007 is used and alsoand applied in Petersen et al. (2013). HQ values are similar to the values obtained for PCDD/F and DL-PCB and are around 0.1 for both adults and children (see Table 3). If the recommended amounts of fish is eaten the exposure will increase and the HQ will increase to over 0.2.

\section{PFOS}

PFAS's such as PFOS have been used for decades in industrial and chemical applications (e.g. impregnation agents, packaging material, and fire foams) and is ubiquitous in humans and biota. Food exposure is, assumed to be the main source of the general population's exposure to PFAS's in general (Fromme et al. 2009). PFOS bio accumulates in humans with a half-life of several years. In 2018 EFSA has set a new and lower temporary TWI for PFOS of $13 \mathrm{ng} \mathrm{kgbw}^{-1} \mathrm{day}^{-1}$ (corresponds to $1.9 \mathrm{ng} \mathrm{kgbw}$ ${ }^{1}$ day $^{-1}$ ) based on effects on the levels on serum cholesterol (EFSA 2018b). In general, the food group 'fish and other seafood's' is an important contributor to the exposure for PFOS in EU and for Danish children and adults EFSA has calculated the exposure to be between $0.49 \mathrm{ng} \mathrm{kgbw}^{-1} \mathrm{day}^{-1}$ and $1.07 \mathrm{ng} \mathrm{kgbw}^{-1} \mathrm{day}^{-1}$. In fish, PFOS was found in all samples of wild fish and fish from marine farms but not in farmed fish from freshwater farms with the exposure in Figure 1d. The level was highest in plaice, which is a bottom-dwelling fish (flatfish). Since the perfluorinated substances accumulate in muscle tissue and not in the lipids, there was no correlation with the fat level, as is the 
case with other organic contaminants, e.g. PCDD/F and DL-PCB (Fromme et al. 2009).

In this study the estimated exposure for adults is $0.39 \mathrm{ng} \mathrm{kgbw}^{-1} \mathrm{day}^{-1}$ and for children $0.52 \mathrm{ng} \mathrm{kgbw}^{-1} \mathrm{day}^{-1}$ (Figure 3). As seen from Table 3 the calculated HQs are less than 1 also if the recommended amount of fish is eaten. However, if children eat the recommended amount of fish per week the exposure from fish alone will amount to more than $80 \%$ of the TWI.

\section{$H B C D D$}

Brominated flame retardants are mixtures of man-made chemicals that are commonly added to a wide variety of industrial and household products to make them less flammable. The main classes of brominated flame retardants includes isomers of HBCDD, and they are present in the environment, e.g. in air, dust, wastewater, sewage sludge, plants and animals (Morris et al. 2004) It is relatively persistent and bioaccumulates, e.g. in fish and meat (Remberger et al. 2004). The calculated exposure to HBCDD is the sum of the three isomers and for Danish population from fish was low with a mean exposure for adults of $0.21 \mathrm{ng} \mathrm{kgbw}^{-1} \mathrm{day}^{-1}$ and $0.18 \mathrm{ng} \mathrm{kgbw}^{-1} \mathrm{day}^{-1}$ for children in this study (see Figure 1e). Only fish has been analysed for HBCD (Petersen et al., 2013, 2015). In other studies a large variation in the exposure to HBCDD is found ranging from $0.067 \mathrm{ng} \mathrm{kgbw}^{-1}$ day $^{-1}$ from fish and fishery products in a Belgian study (Goscinny et al. 2011) to $4.9 \mathrm{ng} \mathrm{kgbw}^{-1} \mathrm{day}^{-1}$ upper bound from fish and fishery products in a British study (Driffield et al. 2008). The Danish mean exposure is lower than the $1.75 \mathrm{ng} \mathrm{kgbw}^{-1} \mathrm{day}^{-1}$ for Swedish women (Lind et al. 2002), mainly due to a relative low Danish fish consumption compared to the other Scandinavian countries (DVFA 2003).

EFSA identified neurodevelopmental effects on behaviour in mice, as the critical end-point for HBCDD and has derived a BMDL 10 of $0.79 \mathrm{mg} \mathrm{kgbw}^{-1}\left(790 \mu \mathrm{g} \mathrm{kgbw}^{-1}\right.$ 
day $^{-1}$ ) and concluded that a margin of exposure (MOE) approach for the health risk assessment of HBCDDs should be used (EFSA 2011). The MOE for children aged 4-14 is $4.3 * 10^{6} 65,000$ based on the mean exposure and adults have a MOE of $4.1 * 10^{6}$ 45,000 (see Table 4). Even at the recommended consumption of fish the MOE is about 1.5 million. The estimated MOE for HBCDD is evaluated to be of no food safety concern (Petersen et al. 2013).

\section{PAH4}

PAHs occur in foods from several sources including deposits from the atmosphere, and the preparation of food during smoking, drying and barbequing. Fish metabolise PAHs and therefore the levels of PAHs in raw fish are generally low (Petersen et al. 2013; Duedahl-Olesen et al. 2010). The most commonly reported PAH is benzo[ $a]$ pyrene, both for concentrations and epidemiological data. EFSA evaluated PAHs in food and found that benzo[a]pyrene is not necessarily the best marker for the total exposure of PAHs (EFSA 2008). The result was a suggestion for the use of the sum of $4 \mathrm{PAH}$, namely benzo $[a]$ pyrene, benz $[a]$ anthracene, benzo $[b]$ fluoranthene and chrysene, as an improved expression for the total exposure to carcinogenic PAHs (EFSA 2008). This approach has been implemented in the EU regulation since 2011 (EC 2006a) and is therefore applied here.

The total mean daily exposure to PAH4 from all food groups was $19 \mathrm{ng} \mathrm{kgbw}{ }^{-1}$ day $^{-1}$ for adults and $31 \mathrm{ng} \mathrm{kgbw}{ }^{-1}$ day $^{-1}$ for children (Petersen et al. 2013). The estimated PAH4 exposure from fish consumption varies from $0.02724 \mathrm{ng} \mathrm{kgbw}^{-1} \mathrm{day}^{-1}$ for adults to $0.025121 \mathrm{ng} \mathrm{kgbw}^{-1} \mathrm{day}^{-1}$ for children (Figure 1f) corresponding to less than $0.1 \%$ of the total exposure for the Danish population, whereas EFSA reported that $7 \%$ of the total exposure to European citizens resulted from fish and fish products (EFSA 2008). 
and milk and milk products (Petersen et al., 2013). The estimated mean exposure value for Danish adults is slightly lower than results from the French total dietary study with means of 0.03 and $0.07 \mathrm{ng} \mathrm{kgbw}^{-1}$ day $^{-1}$ for adults and children (Veyrand et al. 2013) and is due to the lower consumption of fish for the Danish population.

PAHs are considered to be genotoxic and carcinogenic (EFSA 2008) and a $\mathrm{BMDL}_{10}$ of $340 \mu \mathrm{g} \mathrm{kgbw}^{-1} \mathrm{day}^{-1}$ for PAH4 was established by EFSA in 2008. MOEs for the carcinogenic effect of PAH4 were calculated and was found to be more than $1 \underline{1} 5$ and 16 million for both Danish adults and children (see Table 4), respectively. The concentration of PAH4 in smoked fish is much higher than in fresh fish and the mean concentration in different kind of smoked fish on the Danish market is $12.4 \mu \mathrm{g} \mathrm{kg}^{-1}$ resulting in a decrease of MOE to about 100.000, if it is assumed that all fish is eaten as smoked fish. The calculated MOE values indicate that fish consumption does not increase the health risk of PAH4, not even for a recommended consumption of fish (see Table 4).

\section{Discussion on uncertainty and benefits of fish consumption}

The exposure assessments include uncertainties in concentration data as well as in consumption data. Uncertainties in concentration data can be due to e.g. the number of samples or the analytical methods. As it appears in the Supplementary material, for $\underline{\text { some fish species very few samples are analysed and for others, where no concentration }}$ data exists, results are extrapolated from other fish species, both including uncertainties. For fish species with no reported consumption, concentration data are not included. Uncertainties in the consumption data can be due to both under- and over-reporting. It should be noted that setting health based guidance values or BMDLs also includes uncertainties. 
Even though fish consumption contribute to the exposures of the studied contaminants it should be emphasised that fish also contain several beneficial substances (e.g. essential fatty acids, vitamin D, selenium and iodine) (DVFA 2018) which is why the Danish authorities, recommend people, to eat fish, taking into account the specific advices for e.g. pregnant women, women in the child-bearing age, and children.

\section{Conclusion}

The Danish population consume less than half the amount of fish recommended for a healthy diet of $350 \mathrm{~g} \mathrm{week}^{-1}$ for adults and $260 \mathrm{~g} \mathrm{week}^{-1}$ for children. For adults, the highest consumption is of salmon (raw and smoked) followed by plaice and cod whereas children prefer plaice followed by canned tuna and thirdly salmon (raw and smoked).

From a health-based point of view the exposure of $\mathrm{Me}-\mathrm{Hg}$ from fish results in a low risk for the average consumer. Even though the exposure to methyl mercury is lower than the TWI of $1.3 \mu \mathrm{g} \mathrm{kgbw}^{-1}$ week $^{-1}$ it is still recommended that children and pregnant women replace fish with high concentrations of Me-Hg with fish with low Me$\mathrm{Hg}$ concentration. The reason for this recommendation is that high peak intake of Me$\mathrm{Hg}$ may induce adverse effects on the developing brain in the fetus and maybe also in small children.

The calculated mean exposure to Me-Hg, PCB-6, PFOS, and PCDD/Fs and DLPCB the exposure is below the health-based toxicological reference values, i.e. $\mathrm{HQ}<1$, when only the exposure to fish is considered. However, for PCDD/Fs and DL-PCB the exposure is close to the actual TWI-value. For PAHs and HBCDD the MOEs are above 100.000. If the Danish population eat as much fish as recommended by the Danish food authorities, HQs will increase and MOEs will decrease and for PCDD/Fs and DL-PCB the HQ will be $>1$ and thus indicates a possible health risk. 


\section{Acknowledgements}

Jens H Andersen is thanked for contribution to data collection.

\section{Declaration of interest statement}

Authors declare no conflict of interest

\section{References}

[AFSSA] French Food Safety Agency. 2007. Opinion of AFSSA on the establishment of relevant maximum levels for non-dioxin-like polychlorobiphenyls (NDLPCB) in some foods, AFSSA - Request No. 2006-SA-0305. Maisons-Alfort, 23 October 2007.

[ANSES] French Agency for Food, Environment and Occupational Health and Safety. 2011a. Second French Total Diet Study (TDS 2). Report 1, Inorganic contaminants, minerals, persistent organic pollutants, mycotoxins and phytoestrogens, France. ISBN 978-2-11-128699-3.

[ANSES] French Agency for Food, Environment and Occupational Health and Safety. 2011b. Second French Total Diet Study (TDS 2), Report 2, Pesticide Residues, Additives, Acrylamide and poly aromatic hydrocarbons), France ISBN 978-211-128699-3.

Aznar-Alemany Ò, Trabalón L, Jacobs S, Barbosa VL, Tejedor MF, Granby K, Kwadijk C, Cunha SC, Ferrari F, Vandermeersch G, Sioen I; Verbeke W, Vilavert L, Domingo JL, Eljarrat E, Barceló D. 2017. Occurrence of halogenated flame retardants in commercial seafood species available in European markets. Food Chem. Toxicol.104: 35-47.

Cederberg TL, Timm-Heinrich M, Sorensen S, Lund K. 2010. Dioxins and PCB in salmon from the Southern Baltic Sea and reduction in levels during processing. Organohalogen Compounds 72: 1430-1433.

Christensen T. 2001. Outline of GIES: General Intake Estimation System. Fourth Poster at International Food Data Conference: New Trends in the Management and Uses of Food Databases. 24-26 August 2001. Bratislava, Slovakia.

Cirillo T, Montuori P, Mainardi P, Russo I, Fasano E, Triassi M, Amodio-Cocchieri R. 2010. Assessment of the dietary habits and polycyclic aromatic hydrocarbon exposure in primary school children. Food Addit Contam 27: 1025-1039. 
Driffield M, Harmer N, Bradley E, Fernandez, AR, Rose M, Mortimer D, Dicks P. 2008. Determination of brominated flame retardants in food by LC-MS/MS: diastereoisomer-specific hexabromocyclododecane and tetrabromobisphenol A. Food Addit Contam 25: 895-903.

Duedahl-Olesen L, Christensen JH, Højgård A, Granby K, Timm-Heinrich M. 2010. Influence of smoking parameters on the concentration of polycyclic aromatic hydrocarbons (PAHs) in Danish smoked fish. Food Addit Contam Part A. 27:1294-1305.

[DVFA] Danish Veterinary and Food Administration, 2001. Monitoring system for foods, 1993-1997, Part 2, Chemical contaminants. Publication No. 2001:18.

[DVFA] Danish Veterinary and Food Administration, 2003 (Fødevarestyrelsen). Helhedssyn på fisk og fiskevarer [Overall assessment of fish and fish products] FødevareRapport 2003:17 October 2003 Schultz ISBN: 87-91399-31-9 - in Danish.

[DVFA] Danish Veterinary and Food Administration, 2005. Food Monitoring 19982003, Part 1, Chemical contaminants. Publication No. 2005:01.

[DVFA] Danish Veterinary and Food Administration, 2018. 'Alt om kost' Nutrition and labelling homepage on dietary recommendations in Danish (https://altomkost.dk/deofficielleanbefalingertilensundlivsstil/de-officielle$\mathrm{kostraad} / \mathrm{spis}-\mathrm{mere}-\mathrm{fisk} /$ [accessed September $23^{\text {rd } 2018]}$

[DVFA] Danish Veterinary and Food Administration, 2019. "Kontrolresultater" [Results on PCDD/F from Danish Monitoring System] - in Danish (https://www.foedevarestyrelsen.dk/Kontrol/Kontrolresultater/Sider/Forside.aspx [last assessed January $\left.30^{\text {th }} 2020\right]$

[EC] European Commission. 1996. Council directive 96/23/EC on measures to monitor certain substances and residues thereof in live animals and animal products repealing Directives 85/358/EEC and 86/469/EEC and Decisions 89/187/EEC and 91/664/EEC. Off J Eur Communities L125: 10S.

[EC] European Commission. 2002. Commission Directive 2002/69/EC of 26 July 2002 laying down methods of sampling and analysis for the official control of levels of dioxins and dioxin-like PCBs in foodstuffs. Off J Eur Union L209: 00050014 
[EC] European Commission. 2006a. Commission Regulation No. 1881/2006/EC of 19 December 2006 setting maximum levels for certain contaminants in foodstuffs with amendments. Off J Eur Union L 364:5 - 24.

[EC] European Commission. 2006b. Commission Regulation (EC) No 1883/2006 of 19 December 2006 laying down methods of sampling and analysis for the official control of levels of dioxins and dioxin-like PCBs in certain foodstuffs. Off J Eur Union L364:32

[EC] European Commission. 2007. Commission Regulation No. 333/2007/EC of 28 March 2007 laying down the methods of sampling and analysis for the official control of the levels of lead, cadmium, mercury, inorganic tin, 3-MCPD and benzo(a)pyrene in foods with amendments. Off J Eur Union L 88: 29-38.

[EFSA] European Food Safety Authority. 2005. Opinion of the Scientific Committee on a request from EFSA related to a harmonised approach for risk assessment of substances which are both genotoxic and carcinogenic. The EFSA Journal $282: 1-31$.

[EFSA] European Food Safety Authority. 2008, Scientific Opinion of the Panel on Contaminants in the Food Chain on a request from the European Commission on Polycyclic Aromatic Hydrocarbons in Food. The EFSA Journal 724: 1-114.

[EFSA] European Food Safety Authority. 2011. Scientific Opinion on Hexabromocyclododecanes (HBCDDs) in Food. EFSA Panel on Contaminants in the Food Chain (CONTAM) EFSA Journal 9: 2296.

[EFSA] European Food Safety Authority. 2012. Scientific Opinion on the risk for public health related to the presence of mercury and methylmercury in Food, EFSA Journal 10: 2985.

[EFSA] European Food Safety Authority. 2018a. Scientific Opinion on the risk for animal and human health related to the presence of dioxins and dioxin-like PCBs in feed and food. EFSA Panel on Contaminants in the Food Chain (CONTAM). EFSA Journal 16: 5333, 331 pp.

[EFSA] European Food Safety Authority. 2018b. Scientific Opinion on the risk to human health related to the presence of perfluorooctanesulfonic acid and perfluorooctanoic acid in food. EFSA Panel on Contaminants in the Food Chain (CONTAM). EFSA Journal 16:5194, 284 pp. 
Fromberg A, Granby K, Højgård A, Fagt S, Larsen JC. 2011. Estimation of dietary intake of PCB and organochlorine pesticides for children and adults. Food Chem 125: 1179-1187.

Fromme H, Tittlemier SA, Völkel W, Wilhelm M, Twardella D. 2009. Perfluorinated compounds - Exposure assessment for the general population in western countries. Int J Hyg Environ Health 212: 239-270.

[GfK] Growth from Knowledge. 2019. Consumer panel data for fish. https://www.gfk.com/solutions/consumer-panel/ [Accessed October 24 ${ }^{\text {th }}$ ].

Goscinny S, Vandevijvere S, Maleki M, Van Overmeire I, Windal I, Hanot V, Blaude MN, Vleminckx C, Van Loco J. 2011. Dietary intake of hexabromocyclododecane diastereoisomers $(\alpha, \beta, \gamma$-HBCD) in the Belgian adult population. Chemosphere 84: 279-288.

Granby K, Cederberg TL. 2007. LC-MS/MS analysis of Hexabromocyclododecane (HBCD) isomers and Tetrabromobisphenol A (TBBPA) and levels in Danish fish for food consumption. Proceedings of the 4th Int Conf on Brominated Flame Retardants, Amsterdam 24-27 April 2007

[IUPAC] International Union on Pure and Applied Chemistry. 2010. http://agrochemicals.iupac.org/index.php?option=com sobi2\&sobi2Task=sobi2 Details\&catid $=7 \&$ sobi2Id=13. [last assessed October 22 $\left.2^{\text {nd }} 2019\right]$.

Krauss RM, Eckel RH, Howard B, Appel LJ, Daniels SR, Deckelbaum RJ, Erdman JW, Kris-Etherton P, Goldberg IJ, Kotchen TA, Lichtenstein AH, Mitch WE, Mullis R, Robinson K, Wylie-Rosett J, Sachiko SJ, Suttie J, Tribble DL, Bazzarre TL. 2000. AHA Dietary Guidelines Revision 2000: A statement for healthcare professionals from the nutrition Committee of the American Heart Association. Circulation 102: 2284-2299

Larsen EH, Rokkjær I, Christensen T. 2007. Danish Monitoring system for Food 19982003. Content of As, $\mathrm{Cd}, \mathrm{Hg}, \mathrm{Ni}, \mathrm{Pb}$ and $\mathrm{Se}$ and dietary intake by children and Aaults. In Caroli S, ed. The determination of chemical elements in food: Applications for Atomic and Mass spectrometry. Wiley p. 297-332.

Lind Y, Aune M, Atuma S, Becker W, Bjerselius R, Glynn A, Darnerud PO. 2002. Food intake of the brominated flame retardants PBDEs and HBCD in Sweden. Organohalogen compounds 58: 181-184. 
LLobet JM, Falcó G, Bocio A, Domingo JL. 2006. Exposure to Polycyclic Aromatic Hydrocarbons through consumption of edible marine species in Catalonia, Spain. J food protection 69: 2493-2499.

Marti-Cid R, Bocio A, Llobet JM, Domingo JL. 2007. Intake of chemical contaminants through fish and seafood consumption by children of Catalonia, Spain: Health risks. Food Chem Toxicol 45: 1968-1974.

Moon HB, Kim HS, Choi M, Choi HG. 2010. Intake and potential health risk of polycyclic aromatic hydrocarbons associated with seafood consumption in Korea from 2005 to 2007. Arch Environ Contam Toxicol 58: 214-221.

Morris S, Allchin CR, Zegers BN, Haftka JJH, Boon JP, Belpaire C, Leonards PEG, Van Leeuwen SPJ, De Boer J. 2004. Distribution and fate of HBCD and TBBPA brominated flame retardants in North Sea Estuaries and aquatic food webs. Environ Sci Technol 38: 5497-5504.

[NFA] National Food Agency of Denmark, 1990. Food Monitoring in Denmark, Nutrients and Contaminants 1983-1987. Publication No. 195 (September, 1990).

[NFA] National Food Agency of Denmark, 1995. Food Monitoring in Denmark, Nutrients and Contaminants 1988-1992. Publication No. 232 (December, 1995). Pedersen AN, Fagt S, Groth MV, Christensen T, Biltoft-Jensen AP, Matthiessen J, Andersen NL, Kørup K, Hartkopp HB, Ygil KH, et al. 2010. Danskernes kostvaner 2003-2008. Hovedresultater [Dietary habits in Denmark 2003-2008. Main results]. National Food Institute, Technical University of Denmark ISBN 978-87-92158-67-3.

Petersen A, Fromberg A, Andersen JH, Sloth JJ, Granby K, Duedahl-Olesen L, Rasmussen PH, Fagt S, Cederberg TL, Christensen T, et al. 2013. Chemical contaminants 2004-2011. DTU, Technical University of Denmark, National Food Institute. ISBN: 978-87-92763-77-8.

Petersen A, Fromberg A, Andersen JH, Sloth JJ, Granby K, Duedahl-Olesen L, Rasmussen PH, Fagt S, Cederberg TL. 2015. Chemical Contaminants: Food monitoring 2012-2013. DTU, Technical University of Denmark, National Food Institute. ISBN: 978-87-93109-61-2.

Rasmussen RR, Bøge Søndergaard A, Bøknæs N, Cederberg T L, Sloth JJ, Granby K. 2017. Effects of industrial processing on essential elements and regulated and emerging contaminant levels in seafood. Food Chem Toxicol 104: 85-94 
Remberger M, Sternbeck J, Palm A, Kaj L, Strömberg K, Brorström-Lundén E. 2004. The environmental occurrence of hexabromocyclododecane in Sweden. Chemosphere 54: 9-21.

Sørensen S, Lund KH, Cederberg TL, Ballin NZ. 2016. Identification of Baltic Sea salmon based on PCB and dioxin profiles. Food Control 61: 165-171.

Veyrand B, Sirot V, Durand S, Pollono C, Marchand P, Dervilly-Pinel G, Tard A, Leblanc JC, Le Bizec B. 2013. Human dietary exposure to polycyclic aromatic hydrocarbons: results of the second French Total Diet Study. Environ Int 54: 1117. 
Table 1. Mean concentrations of contaminants used in the exposure calculations.

\begin{tabular}{|c|c|c|c|c|c|c|}
\hline Seafood & $\begin{array}{c}\text { PAH4 } \\
\left(\mathrm{ng} \mathrm{kg}^{-1}\right) \\
\end{array}$ & $\begin{array}{c}\mathrm{Hg} \\
\left.(\mu \mathrm{g} \mathrm{kg})^{-1}\right) \\
\end{array}$ & $\begin{array}{c}\text { HBCDCD } \\
\left.(\mu \mathrm{g} \mathrm{kg})^{-1}\right)\end{array}$ & $\begin{array}{c}\text { PFOS } \\
\left(\mu \mathrm{g} \mathrm{kg} \mathbf{~}^{-1}\right)\end{array}$ & $\begin{array}{c}\text { PCB6 } \\
\left.(\mu \mathrm{g} \mathrm{kg})^{-1}\right) \\
\end{array}$ & $\begin{array}{c}\text { WHO- } \\
\text { TEQ } \\
\text { PCDD/F } \\
\text { and DL- } \\
\text { PCB } \\
\left(n g k^{-1}\right)\end{array}$ \\
\hline Cod liver, canned & n.a. & 17.0 & 11 & 1.30 & $229 \theta$ & 39 \\
\hline Cod roe, canned & n.a. & 5.4 & $\underline{0.12 \text { n.a. }}$. & 1.30 & 3.4 & 0.62 \\
\hline Cod, fillet raw & n.a. & $\underline{5958.7}$ & 0.02 & 1.30 & 0.82 & 0.17 \\
\hline Eel, raw & n.a. & 178 & 1.21 & 1.30 & 19 & 2.6 \\
\hline Eel, smoked & 1870 & 178 & 1.21 & 1.30 & 19 & 2.6 \\
\hline Garfish, raw & 5.9 & $71 z$ & 0.004 & 1.30 & 9.5 & 0.84 \\
\hline $\begin{array}{l}\text { Greenland halibut, } \\
\text { smoked }\end{array}$ & 130 & n.a. & n.a. & n.a. & 3.4 & 0.62 \\
\hline Herring, marinated & 20 & 42 & 1.27 & 1.60 & 6.15 & 1.0 \\
\hline Herring, raw & 20 & 42 & 1.27 & 1.60 & 6.15 & 1.0 \\
\hline $\begin{array}{l}\text { Mackerel, canned in } \\
\text { tomato sauce }\end{array}$ & $70 \underline{61}$ & 30 & 0.93 & 1.30 & 3.4 & 0.67 \\
\hline Mackerel, raw & $70 \overline{61}$ & 34 & 0.93 & 1.30 & 3.4 & 0.67 \\
\hline Mackerel, smoked & $148 \overline{540}$ & 34 & 0.93 & n.a. & 3.4 & 0.67 \\
\hline Plaice & n.a. & 437 & 0.004 & 3.30 & 3.6 & 0.94 \\
\hline Saithe (UK) fillet & n.a. & 59 & 0.02 & 1.30 & 0.77 & 0.14 \\
\hline Salmon, raw & 20 & 11 & 2.45 & 0.50 & 4.1 & 0.58 \\
\hline Salmon, smoked & $\underline{2450} 1420$ & 11 & 2.45 & 0.50 & 4.1 & 0.58 \\
\hline Shrimps, canned & n.a. & 22 & 0.004 & 0.50 & 0.04 & 0.03 \\
\hline Shrimps, frozen & n.a. & 22 & 0.004 & 0.50 & 0.04 & 0.03 \\
\hline Trout, Rainbow & n.a. & 17 & $\underline{0.35 \mathrm{n} . \mathrm{a} .}$ & n.a. & 2.5 & 0.35 \\
\hline Tuna, canned oil & n.a. & 410 & 0.004123 & 1.30 & 0.19 & 0.06 \\
\hline Tuna, canned water & n.a. & $\underline{410194}$ & $\overline{0.004}$ & 1.30 & 0.19 & 0.06 \\
\hline Fish oil & n.a. & 0.8 & n.a. & n.a. & 0.19 & 0.09 \\
\hline
\end{tabular}

n.a.: not analysed and no read-across from other fish species has been performed. 
Table 2. Fish consumption (g day ${ }^{-1}$ ) for Danish adults (aged 15-75) and children (aged 4-14) (Data from Pedersen et al. 2010). Number of consumers are given in parentheses for Fish eaters only column.

\begin{tabular}{l|ccc|ccc}
\hline & \multicolumn{3}{|c|}{ Adults } & \multicolumn{2}{c}{ Children } \\
\hline Fish products & All & Fish eaters & $\begin{array}{c}\text { Fish eaters only } \\
\text { (No. of consumers) }\end{array}$ & All & Fish eaters & $\begin{array}{c}\text { Fish eaters only } \\
\text { (No. of consumers) }\end{array}$ \\
\hline Consumers total, N & 2133 & 1949 & 1949 & 567 & 467 & 467 \\
\hline Cod, fillet raw & 3.15 & 3.44 & $9.45(710)$ & 1.60 & 1.94 & $6.16(147)$ \\
Cod roe, canned & 0.79 & 0.86 & $6.32(265)$ & 0.68 & 0.82 & $5.35(72)$ \\
Cod liver, canned & 0.01 & 0.01 & $5.57(2)$ & - & - & - \\
Eel, raw & 0.25 & 0.27 & $28.0(19)$ & - & - & - \\
Eel, smoked & 0.21 & 0.22 & $0.46(952)$ & 0.09 & 0.11 & $0.35(153)$ \\
Garfish, raw & 0.14 & 0.16 & $14.4(21)$ & 0.07 & 0.09 & $8.02(5)$ \\
Greenland halibut, & 0.04 & 0.04 & $8.87(9)$ & 0.02 & 0.03 & $12.9(1)$ \\
smoked & & & & & \\
Herring, raw & 0.51 & 0.55 & $15.9(68)$ & 0.14 & 0.17 & $9.78(8)$ \\
Herring, marinated & 2.28 & 2.49 & $4.39(1106)$ & 1.02 & 1.24 & $9.87(169)$ \\
Mackerel, canned & 1.13 & 1.24 & $2.18(1113)$ & 0.58 & 0.70 & $1.54(212)$ \\
in tomato sauce & & & & & \\
Mackerel, raw & 0.29 & 0.32 & $14.9(42)$ & 0.18 & 0.22 & $7.94(13)$ \\
Mackerel, smoked & 0.32 & 0.36 & $0.74(952)$ & 0.15 & 0.18 & $0.56(153)$ \\
Plaice & 3.20 & 3.50 & $14.3(607)$ & 2.47 & 3.00 & $9.21(152)$ \\
Salmon, raw & 2.94 & 3.22 & $15.7(399)$ & 1.46 & 1.77 & $12.7(65)$ \\
Salmon, smoked & 0.38 & 0.41 & $0.84(958)$ & 0.17 & 0.21 & $0.63(153)$ \\
Saithe fillet & 0.09 & 0.10 & $8.64(31)$ & 0.25 & 0.30 & $7.20(21)$ \\
Shrimps, canned & 1.58 & 1.73 & $4.27(788)$ & 0.66 & 0.81 & $2.92(129)$ \\
Shrimps, frozen & 1.05 & 1.15 & $2.09(1074)$ & 0.34 & 0.41 & $1.12(171)$ \\
Tuna, canned water & 1.82 & 1.99 & $4.50(864)$ & 1.98 & 2.41 & $4.54(248)$ \\
Tuna, canned oil & 0.36 & 0.39 & $2.19(348)$ & 0.28 & 0.34 & $1.83(86)$ \\
Trout, Rainbow & 0.37 & 0.41 & $13.2(60)$ & 0.24 & 0.29 & $15.2(9)$ \\
\hline & & & & & & \\
\end{tabular}




\begin{tabular}{lcccccc}
\hline Others* & 0.11 & 0.13 & - & 0.05 & 0.06 & - \\
Fish (total) & 21.0 & 23.0 & - & 12.4 & 15.1 & $0.67(42)$ \\
Fish oil (supplement) & 0.24 & 0.26 & $0.81(632)$ & 0.05 & 0.06 & - \\
Fatty fish ${ }^{\text {a) }}$ Mean & 8.33 & 9.11 & - & 3.80 & 4.60 & - \\
\hline Lean fish b) Mean & 9.96 & 10.9 & - & 7.60 & 9.21 & - \\
\hline
\end{tabular}

*Others includes mussels, lobster, caviar, crabs and octopus.

a) sum of cod liver, eel, herring, mackerel and salmon

b) sum of cod, garfish, plaice, halibut, saithe and trout

- not relevant or no data available 
Table 3. HQ for Me-Hg, PCDD/F and DL-PCB, PCB6 and PFOS for adults (aged 15-75 years) and children (aged 4-14 years) for both all consumers and Fish eaters.

\begin{tabular}{|c|c|c|c|c|}
\hline & Adults & $\begin{array}{c}\text { Adults, } \\
\text { Fish eaters }\end{array}$ & Children & $\begin{array}{c}\text { Children, Fish } \\
\text { eaters }\end{array}$ \\
\hline \multicolumn{5}{|c|}{ Me-Hg. TWI $=1.3 \mu \mathrm{g} \mathrm{kgbw}^{-1}$ week $^{-1}=0.19 \mu \mathrm{g} \mathrm{kgbw}^{-1}$ week-1 $($ EFSA 2012) } \\
\hline Sum & 0.11087 & 0.13095 & 0.1913 & $0.162 \underline{\underline{2}}$ \\
\hline Fatty fish & $\overline{0.019}$ & $\overline{0.02}$ & $0 . \overline{014}$ & $0.0 \overline{17}$ \\
\hline Lean fish & 0.025 & 0.027 & 0.033 & 0.041 \\
\hline $\begin{array}{l}\text { Recommended } \\
\text { consumption a) }\end{array}$ & $0.2 \underline{7}+$ & - & $0.3 \underline{5} 9$ & - \\
\hline \multicolumn{5}{|c|}{ PCDD/F and DL-PCB. TWI $=2 \mathrm{pg} \mathrm{kgbw}^{-1} \mathrm{week}^{-1}=0.29 \mathrm{pg} \mathrm{kgbw}^{-1}$ week $^{-1}(\mathrm{EFSA}$} \\
\hline Sum & 0.57 & 0.62 & $0.6 \underline{1 z}$ & 0.75 \\
\hline Fatty fish & $0.3 \underline{3} \theta$ & 0.36 & $0 . \overline{27}$ & 0.32 \\
\hline Lean fish & $0 . \overline{18}$ & 0.20 & 0.27 & 0.33 \\
\hline $\begin{array}{l}\text { Recommended } \\
\text { consumption a) }\end{array}$ & 1.35 & $=$ & 1.85 & $=$ \\
\hline \multicolumn{5}{|c|}{ PCB-6. TDI = $10 \mathrm{ng} \mathrm{kgbw}^{-1} \mathrm{day}^{-1}($ AFSSA 2007) } \\
\hline Sum & 0.091 & 0.099 & 0.092 & 0.11 \\
\hline Fatty fish & 0.059 & 0.064 & 0.047 & 0.057 \\
\hline Lean fish & 0.022 & 0.024 & 0.032 & 0.039 \\
\hline $\begin{array}{l}\text { Recommended } \\
\text { consumption a) }\end{array}$ & 0.22 & & 0.27 & - \\
\hline \multicolumn{5}{|c|}{ PFOS. TWI $=13 \mathrm{ng} \mathrm{kgbw}^{-1} \mathrm{week}^{-1}=1.9 \mathrm{ng} \mathrm{kgbw}^{-1} \mathrm{day}^{-1}($ EFSA 2018b) } \\
\hline Sum & 0.21 & 0.23 & 0.28 & 0.34 \\
\hline Fatty fish & 0.060 & 0.066 & 0.055 & 0.066 \\
\hline Lean fish & 0.11 & 0.12 & 0.16 & $0 . \underline{2019}$ \\
\hline $\begin{array}{l}\text { Recommended } \\
\text { consumption a) }\end{array}$ & 0.50 & $=$ & 0.84 & $=$ \\
\hline
\end{tabular}

a) $50 \mathrm{~g}$ per day for adults and $37.1 \mathrm{~g} \mathrm{day}^{-1}$ for children

- No values calculated 
Table 4. MOEs for HBCDD and PAH in $10^{6}$ for adults (aged 15-75 years) and children (aged 4-14 years) for both all consumers and Fish eaters.

\begin{tabular}{|c|c|c|c|c|}
\hline & Adults & $\begin{array}{c}\text { Adults. Fish } \\
\text { eaters }\end{array}$ & Children & $\begin{array}{l}\text { Children. } \\
\text { Fish eaters }\end{array}$ \\
\hline \multicolumn{5}{|c|}{ HBCDCD BMDL ${ }_{10}=790 \mu \mathrm{g} \mathrm{kgbw}^{-1}($ EFSA 2011) } \\
\hline Sum & 4.1 & 3.78 & $4 . \underline{34}$ & $3 . \underline{56}$ \\
\hline Fatty fish & 4.3 & 3.9 & 4.5 & 3.7 \\
\hline Lean fish & 282750 & 684255 & 217600 & 179500 \\
\hline $\begin{array}{l}\text { Recommended } \\
\text { consumption a) }^{\text {and }}\end{array}$ & 1.7 & - & 1.5 & - \\
\hline \multicolumn{5}{|c|}{ PAH4 BMDL10 $=340 \mu \mathrm{g} \mathrm{kgbw}^{-1}($ EFSA 2008) } \\
\hline Sum & 125 & 124 & $17 \underline{3}$ & 131 \\
\hline Fatty fish & $\underline{15} z 0$ & $19 \underline{4}$ & $21 \underline{16}=$ & $17 \underline{13}$ \\
\hline Lean fish & 30460 & 26700 & 29600 & 23100 \\
\hline $\begin{array}{l}\text { Recommended } \\
\text { consumption a) }\end{array}$ & $\underline{5.26 .5}$ & - & $\underline{4.35} 5.5$ & - \\
\hline
\end{tabular}



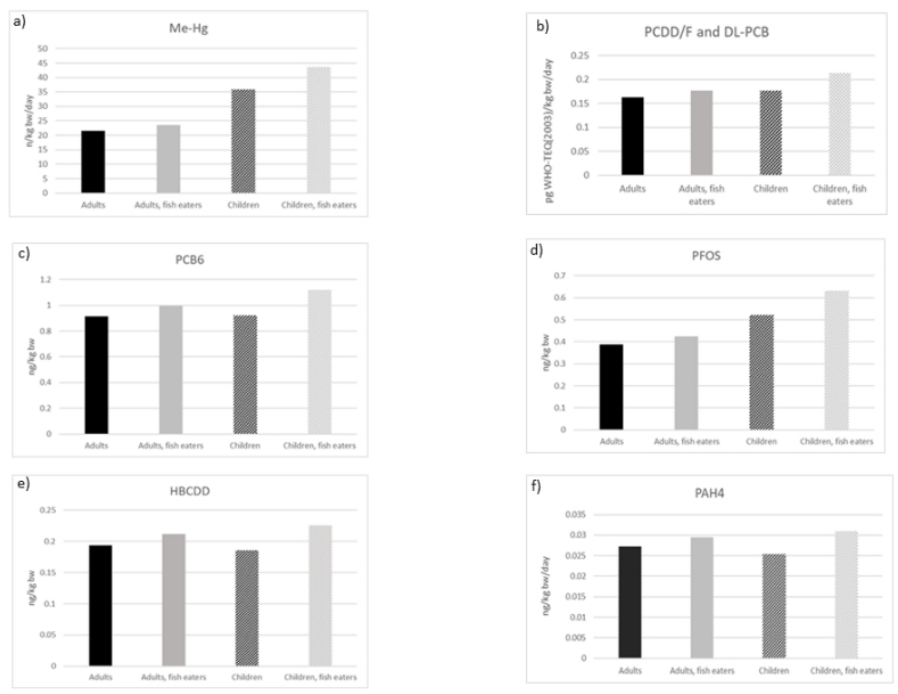

Figure 1. Exposure to Me-Hg (a), PCDD/F and DL-PCB (b), PCB6 (c), PFOS (d), HBCDD (e), PAH4 (f) for Danish adults (full color) and children (hatching), mean (black) and as Fish eaters (grey).

$338 \times 190 \mathrm{~mm}(96 \times 96 \mathrm{DPI})$ 
S1. Mean concentrations of $\mathrm{Hg}$ in $\mu \mathrm{g} \mathrm{kg}^{-1}$ with sample numbers, positive samples, minimum, maximum concentrations and comments with respective references.

\begin{tabular}{|c|c|c|c|c|c|c|c|}
\hline Seafood & $\begin{array}{c}\mathbf{H g} \\
\left(\mu \mathrm{kgg}^{-1}\right)\end{array}$ & $\begin{array}{c}\text { No. of } \\
\text { samples }\end{array}$ & Positive & $\underset{\left(\mu g \mathrm{~kg}^{-1}\right)}{\operatorname{Min} .}$ & $\begin{array}{c}\text { Max. } \\
\left(\mu \mathrm{g} \mathrm{kg}^{-1}\right)\end{array}$ & Comments & References \\
\hline Cod liver, canned & 17.0 & 10 & 9 & $<2.6$ & 47.9 & & DVFA, 2005 \\
\hline Cod roe, canned & 5.4 & & & & & Estimated from cod, raw & $\begin{array}{c}\text { DVFA, 2005, } \\
\text { Petersen et al., 2013, } \\
\text { Petersen et al., 2015 } \\
\end{array}$ \\
\hline Cod, fillet raw & 59 & 50 & 50 & 14 & 160 & & $\begin{array}{c}\text { DVFA, 2005, } \\
\text { Petersen et al., 2013, } \\
\text { Petersen et al., 2015 }\end{array}$ \\
\hline Eel, raw & 178 & 8 & 8 & 20.5 & 488 & & DVFA, 2005 \\
\hline Eel, smoked & 178 & & & 8 & & Read-across from eel, raw & \\
\hline Garfish, raw & 71 & 15 & 15 & 29.9 & 184 & & DVFA, 2005 \\
\hline $\begin{array}{l}\text { Greenland halibut, } \\
\text { smoked }\end{array}$ & n.a. & & & & & & \\
\hline Herring, marinated & 42 & & & & 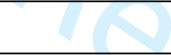 & Read-across from herring, raw & \\
\hline Herring, raw & 42 & 24 & 24 & 18.1 & 77 & & $\begin{array}{c}\text { DVFA, 2005, } \\
\text { Petersen et al., 2013, } \\
\text { Petersen et al., 2015 }\end{array}$ \\
\hline $\begin{array}{l}\text { Mackerel, canned in } \\
\text { tomato sauce }\end{array}$ & 30 & & & & & Estimated from mackerel, raw & \\
\hline Mackerel, raw & 34 & 22 & 22 & 22.2 & 44.7 & 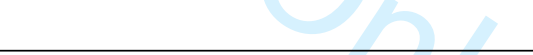 & DVFA, 2005 \\
\hline Mackerel, smoked & 34 & & & & & $\begin{array}{c}\text { Read-across from mackerel, } \\
\text { raw }\end{array}$ & \\
\hline Plaice & 43 & 28 & 28 & 2.9 & 80.4 & & $\begin{array}{c}\text { DVFA, 2005, } \\
\text { Petersen et al., 2013, } \\
\text { Petersen et al., 2015 }\end{array}$ \\
\hline Saithe (UK) fillet & 59 & & & & & Read-across from cod, raw & \\
\hline Salmon, raw & 11 & 4 & 4 & 6 & 14 & & Petersen et al., 2013 \\
\hline Salmon, smoked & 11 & & & & & Read-across from salmon, raw & \\
\hline Shrimps, canned & 22 & 78 & 78 & $<1$ & 180 & $\begin{array}{l}\text { Estimated from data on } \\
\text { shrimps from cold and warm }\end{array}$ & $\begin{array}{c}\text { DVFA, 2005, } \\
\text { Petersen et al., } 2015\end{array}$ \\
\hline
\end{tabular}




\begin{tabular}{|l|c|c|c|c|c|c|c|}
\hline & & & & & & $\begin{array}{c}\text { water as well as unspecified } \\
\text { shrimps }\end{array}$ & \\
\hline Shrimps, frozen & 22 & & & & & See shrimps, canned & \\
\hline Trout, Rainbow & 31 & 12 & 69 & & & & Petersen et al., 2013 \\
\hline Tuna, canned oil & 410 & 5 & 5 & 43 & 900 & & Petersen et al., 2015 \\
\hline Tuna, canned water & 410 & & & & & Read-across from tuna in oil & \\
\hline Fish oil & n.a. & & & & & & \\
\hline
\end{tabular}

n.a.: not analysed and no read-across from other fish species has been performed. 
$\mathrm{S} 2$. Mean concentrations of PCDD/F and DL-PCB in $\mathrm{ng} \mathrm{kg}^{-1}$ with sample numbers, positive samples, minimum, maximum concentrations and comments with respective references.

\begin{tabular}{|c|c|c|c|c|c|c|c|}
\hline Seafood & $\begin{array}{c}\text { WHO-TEQ } \\
\text { (WHO-2005) } \\
\text { PCDD/F and } \\
\text { DL-PCB } \\
\left(\mathrm{ng} \mathrm{kg}^{-1}\right) \\
\end{array}$ & $\begin{array}{l}\text { Number of } \\
\text { samples }\end{array}$ & Positive & $\underset{\left(\mathrm{ng} \mathrm{kg}^{-1}\right)}{\operatorname{Min}}$ & $\underset{\left(\text { ng kg }^{-1}\right)}{\operatorname{Max}}$ & Comments & References \\
\hline Cod liver, canned & 39 & 8 & 8 & 0.86 & 63 & & Petersen et al., 2013 \\
\hline Cod roe, canned & 0.62 & 4 & 4 & 0.16 & 1.2 & Read-across from flounder & \\
\hline Cod, fillet raw & 0.17 & 30 & 6 & 0.11 & 0.29 & Samples 2012-2016. & $\begin{array}{c}\text { Petersen et al., 2013, } \\
\text { Petersen et al., 2015 } \\
\text { DVFA, } 2020 \text { in Danish }\end{array}$ \\
\hline Eel, raw & 2.6 & 11 & 11 & 1.3 & 4.5 & wild & \\
\hline Eel, smoked & 2.6 & +4 & 11 & 1.3 & 4.5 & Read-across from eel, raw & Petersen et al., 2013 \\
\hline Garfish, raw & 0.84 & 5 & 5 & 0.31 & 1.4 & Samples 2012-2016 & $\begin{array}{c}\text { Petersen et al., 2013, } \\
\text { Petersen et al., } 2015 \\
\text { DFVA, } 2020 \text { in Danish }\end{array}$ \\
\hline $\begin{array}{l}\text { Greenland halibut, } \\
\text { smoked }\end{array}$ & 0.62 & 4 & 4 & 0.16 & 1.2 & Read-across from flounder & \\
\hline Herring, marinated & 1.0 & 8 & 8 & 0.84 & 1.5 & Read-across from herring, raw & \\
\hline Herring, raw & 1.0 & 8 & 8 & 0.84 & 1.5 & & Petersen et al., 2013 \\
\hline $\begin{array}{l}\text { Mackerel, canned in } \\
\text { tomato sauce }\end{array}$ & 0.67 & 12 & 12 & 0.23 & 3.27 & $\begin{array}{c}\text { Read-across from mackerel, } \\
\text { raw }\end{array}$ & \\
\hline Mackerel, raw & 0.67 & 12 & 12 & 0.23 & 3.27 & 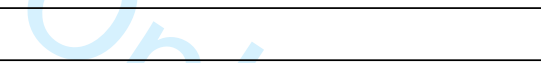 & Petersen et al., 2013 \\
\hline Mackerel, smoked & 0.67 & 12 & 12 & 0.23 & 3.27 & $\begin{array}{c}\text { Read-across from mackerel, } \\
\text { raw }\end{array}$ & \\
\hline Plaice & 0.94 & 8 & 8 & & & Samples 2012-2016 & $\begin{array}{c}\text { Petersen et al., 2013, } \\
\text { Petersen et al., } 2015 \\
\text { DVFA, } 2020 \text { in Danish }\end{array}$ \\
\hline Saithe (UK) fillet & 0.14 & 3 & 3 & & & Min. and max. not stated & \\
\hline Salmon, raw & 0.58 & 31 & 31 & 0.10 & 3.1 & & Petersen et al., 2013 \\
\hline Salmon, smoked & 0.58 & 31 & 31 & 0.10 & 3.1 & Read-across from Salmon, raw & \\
\hline Shrimps, canned & 0.03 & 10 & 10 & 0.02 & 0.03 & $\begin{array}{l}\text { Read-across from shrimps raw. } \\
\text { From Greenland }\end{array}$ & \\
\hline Shrimps, frozen & 0.03 & 10 & 10 & 0.02 & 0.03 & $\begin{array}{l}\text { Read-across from shrimps raw. } \\
\text { From Greenland }\end{array}$ & \\
\hline
\end{tabular}




\begin{tabular}{|l|c|c|c|c|c|c|c|}
\hline Trout, Rainbow & 0.35 & 44 & 44 & 0.04 & 1.2 & Aquaculture & Petersen et al., 2013 \\
\hline Tuna, canned oil & 0.06 & 6 & 6 & 0.05 & 2.3 & Read-across from tuna & Read-across from tuna \\
\hline Tuna, canned water & 0.06 & 6 & 6 & 0.05 & 2.3 & & $\begin{array}{c}\text { Not included in exposure } \\
\text { assessment }\end{array}$ \\
\hline Fish oil & & & & & & \\
\hline
\end{tabular}


S3. Mean concentrations of PCB6 in $\mu \mathrm{g} \mathrm{kg}^{-1}$ with sample numbers, positive samples, minimum, maximum concentrations and comments with respective references.

\begin{tabular}{|c|c|c|c|c|c|c|c|}
\hline Seafood & $\begin{array}{c}\text { PCB6 } \\
\left.(\mu \mathrm{g} \mathrm{kg})^{-1}\right)\end{array}$ & $\begin{array}{c}\text { Number of } \\
\text { samples }\end{array}$ & Positive & $\begin{array}{c}\text { Min. } \\
\left(\mu \mathrm{g} \mathrm{kg}^{-1}\right)\end{array}$ & $\begin{array}{c}\text { Max. } \\
\left(\mu g \mathrm{~kg}^{-1}\right)\end{array}$ & Comments & References \\
\hline Cod liver, canned & 229 & 8 & 8 & 59 & 477 & & Petersen et al., 2013 \\
\hline Cod roe, canned & 3.4 & 4 & 4 & 0.45 & 5.3 & Read-across from flounder & \\
\hline Cod, fillet raw & 0.82 & 6 & 6 & 0.62 & 1.5 & Samples 2012-2016. & $\begin{array}{l}\text { Petersen et al., 2013, } \\
\text { Petersen et al., } 2015 \\
\text { DVFA, } 2020 \text { in Danish }\end{array}$ \\
\hline Eel, raw & 19 & 11 & 11 & 9.1 & 34 & & \\
\hline Eel, smoked & 19 & 11 & 11 & 9.1 & 34 & Read-across from eel, raw & Petersen et al., 2013 \\
\hline Garfish, raw & 9.5 & 5 & 5 & 3.5 & 15 & Samples 2012-2016 & $\begin{array}{c}\text { Petersen et al., 2013, } \\
\text { Petersen et al., } 2015 \\
\text { DVFA, } 2020 \text { in Danish }\end{array}$ \\
\hline $\begin{array}{l}\text { Greenland halibut, } \\
\text { smoked }\end{array}$ & 3.4 & 4 & 4 & 0.45 & 5.3 & Read-across from flounder & \\
\hline Herring, marinated & 6.1 & 8 & 8 & 4.5 & 7.4 & Read-across from herring, raw & \\
\hline $\begin{array}{l}\text { Mackerel, canned in } \\
\text { tomato sauce }\end{array}$ & 3.4 & 12 & 12 & 1.2 & 22 & Read-across from mackerel, raw & \\
\hline Mackerel, raw & 3.4 & 12 & 12 & 1.2 & 22 & 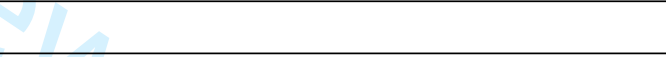 & Petersen et al., 2013 \\
\hline Mackerel, smoked & 3.4 & 12 & 12 & 1.2 & 22 & Read-across from mackerel, raw & \\
\hline Plaice & 3.6 & 8 & 8 & & & $\begin{array}{c}\text { Samples 2012-2016. } \\
\text { Min. and max. not stated }\end{array}$ & $\begin{array}{c}\text { Petersen et al., 2013, } \\
\text { Petersen et al., } 2015 \\
\text { DVFA, } 2020 \text { in Danish }\end{array}$ \\
\hline Saithe (UK) fillet & 0.77 & 3 & 3 & & & $\begin{array}{l}\text { Samples 2012-2016. } \\
\text { Min. and max. not stated }\end{array}$ & DVFA, 2020 in Danish \\
\hline Salmon, raw & 4.1 & 31 & 31 & 0.36 & 18 & & Petersen et al., 2013 \\
\hline Salmon, smoked & 4.1 & 31 & 31 & 0.36 & 18 & Read-across from Salmon, raw & \\
\hline Shrimps, canned & 0.04 & 10 & 10 & 0.03 & 0.07 & $\begin{array}{l}\text { Read-across from shrimps raw. From } \\
\text { Greenland }\end{array}$ & \\
\hline Shrimps, frozen & 0.04 & 10 & 10 & 0.03 & 0.07 & $\begin{array}{l}\text { Read-across from shrimps raw. From } \\
\text { Greenland }\end{array}$ & \\
\hline Tuna, canned oil & 0.19 & 6 & 6 & 0.05 & 8.1 & Read-across from tuna & \\
\hline Tuna, canned water & 0.19 & 6 & 6 & 0.05 & 8.1 & Read-across from tuna & \\
\hline
\end{tabular}




\section{Page 39 of 44}

Fish oil

\begin{tabular}{|l|l|l|} 
& \\
& &
\end{tabular}

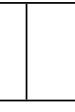

Not included in exposure assessment

n.a.: not analysed and no read-across from other fish species has been performed. 
S4. Mean concentrations of PFOS in $\mu \mathrm{g} \mathrm{kg}^{-1}$ with sample numbers, positive samples, minimum, maximum concentrations and comments with respective references.

\begin{tabular}{|c|c|c|c|c|c|c|c|}
\hline Seafood & $\begin{array}{c}\text { PFOS } \\
\left(\mu g \mathrm{~kg}^{-1}\right)\end{array}$ & $\begin{array}{c}\text { No of } \\
\text { samples }\end{array}$ & Positive & $\underset{\left(\mu g \mathrm{~kg}^{-1}\right)}{\operatorname{Min} .}$ & $\begin{array}{c}\text { Max. } \\
\left(\mu \mathrm{kg}^{-1}\right)\end{array}$ & Comments & References \\
\hline Cod liver, canned & 1.30 & & & & & Read-cross from cod, raw & \\
\hline Cod roe, canned & 1.30 & & & & & Read-cross from cod, raw & \\
\hline Cod, fillet raw & 1.30 & 1 & 1 & & 1.3 & & Petersen et al., 2013 \\
\hline Eel, raw & 1.30 & 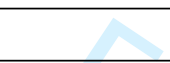 & & & & Read-cross from cod, raw & \\
\hline Eel, smoked & 1.30 & $8+$ & & & & Read-cross from cod, raw & \\
\hline Garfish, raw & 1.30 & & & & & Read-cross from cod, raw & \\
\hline $\begin{array}{l}\text { Greenland halibut, } \\
\text { smoked }\end{array}$ & n.a. & & & & & & \\
\hline Herring, marinated & 1.60 & & & $+\sqrt{x}$ & & Read-cross from herring, raw & \\
\hline Herring, raw & 1.60 & 6 & 6 & 1.3 & 2 & & Petersen et al., 2013 \\
\hline $\begin{array}{l}\text { Mackerel, canned in } \\
\text { tomato sauce }\end{array}$ & 1.30 & & & +2 & & Read-cross from cod, raw & \\
\hline Mackerel, raw & 1.30 & & & & +2 & Read-cross from cod, raw & \\
\hline Mackerel, smoked & n.a. & & & & & 8 & \\
\hline Plaice & 3.30 & 1 & 1 & & 3.3 & 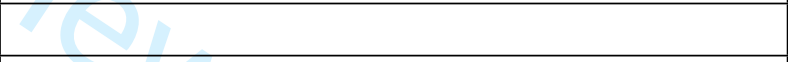 & Petersen et al., 2013 \\
\hline Saithe (UK) fillet & 1.3 & 2 & 2 & 1.1 & 1.7 & 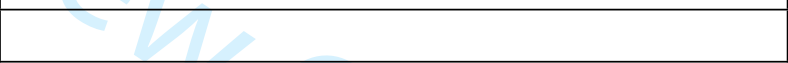 & Non-published data \\
\hline Salmon, raw & 0.50 & & & & & $\begin{array}{c}\text { Not analysed but LOD of } 0.5 \mu \mathrm{g} / \mathrm{kg} \text { is used in } \\
\text { the exposure calculation }\end{array}$ & \\
\hline Salmon, smoked & 0.50 & & & & & $\begin{array}{l}\text { Not analysed but LOD of } 0.5 \mu \mathrm{g} / \mathrm{kg} \text { is used in } \\
\text { the exposure calculation }\end{array}$ & \\
\hline Shrimps, canned & 0.50 & & & & & $\begin{array}{l}\text { Not analysed but LOD of } 0.5 \mu \mathrm{g} / \mathrm{kg} \text { is used in } \\
\text { the exposure calculation }\end{array}$ & \\
\hline Shrimps, frozen & 0.50 & & & & & $\begin{array}{l}\text { Not analysed but LOD of } 0.5 \mu \mathrm{g} / \mathrm{kg} \text { is used in } \\
\text { the exposure calculation }\end{array}$ & \\
\hline $\begin{array}{l}\text { Trout, Rainbow } \\
\text { (farmed) }\end{array}$ & 0.5 & 4 & 4 & $<0.5$ & 0.53 & $\begin{array}{c}\mathrm{LOD}=0.5 \mu \mathrm{g} / \mathrm{kg} \text { is used in the calculation of } \\
\text { mean used for the exposure calculation }\end{array}$ & Petersen et al., 2013 \\
\hline Tuna, canned oil & 1.30 & & & & & Read-cross from cod, raw & \\
\hline Tuna, canned water & 1.30 & & & & & Read-cross from cod, raw & \\
\hline Fish oil & n.a. & & & & & & \\
\hline
\end{tabular}


n.a.: not analysed and no read-across from other fish species has been performed. 
S5. Mean concentrations of HBCDD in $\mu \mathrm{g} \mathrm{kg}^{-1}$ with sample numbers, positive samples, minimum, maximum concentrations and comments with respective references.

\begin{tabular}{|c|c|c|c|c|c|c|c|}
\hline Seafood & $\begin{array}{l}\text { HBCDD } \\
\left(\mu \mathrm{g} \mathrm{kg}^{-1}\right)\end{array}$ & $\begin{array}{c}\text { No of } \\
\text { samples }\end{array}$ & Positive & $\underset{\left(\mu \mathrm{g} \mathrm{kg}^{-1}\right)}{\operatorname{Min} .}$ & $\begin{array}{c}\text { Max. } \\
\left(\mu g \text { kg }^{-1}\right)\end{array}$ & Comments & Reference \\
\hline Cod roe, canned & 0.12 & & & & & $\begin{array}{l}\text { Estimated from other cod } \\
\text { products }\end{array}$ & \\
\hline Cod, fillet raw & 0.02 & 1 & 1 & & 0.02 & & Petersen et al., 2013 \\
\hline Eel, raw (farmed) & 1.21 & 3 & 3 & 1.49 & 1.78 & & Petersen et al., 2013 \\
\hline Eel, smoked & 1.21 & & +2 & & & Read-across from Eel, raw & \\
\hline Herring, marinated & 1.27 & & & +1 & $\sqrt{10}$ & Read-across from Herring, raw & \\
\hline Herring, raw & 1.27 & 20 & 20 & 0.403 & 3.73 & & Petersen et al., 2013 \\
\hline $\begin{array}{l}\text { Mackerel, canned in } \\
\text { tomato sauce }\end{array}$ & 0.93 & & & & +4 & $\begin{array}{l}\text { Read-across from Mackerel, } \\
\text { raw }\end{array}$ & \\
\hline Mackerel, raw & 0.93 & 13 & 13 & 0.317 & 6.35 & 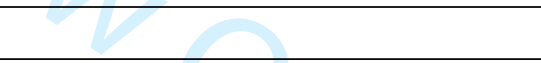 & Petersen et al., 2013 \\
\hline Salmon, raw (farmed) & 2.45 & 9 & 9 & 1.59 & 3.57 & & Petersen et al., 2013 \\
\hline Salmon, smoked & 2.45 & & & & & Read-across from Salmon, raw & \\
\hline Shrimps, canned & 0.004 & & & & & Read-across from Plaice & \\
\hline Shrimps, frozen & 0.004 & & & & & Read-across from Plaice & \\
\hline Trout, Rainbow & 0.35 & 1 & 1 & & 0.35 & & Petersen et al., 2013 \\
\hline Tuna, canned oil & 0.004 & & & & & Read-across from Plaice & \\
\hline
\end{tabular}




\begin{tabular}{|l|c|l|l|l|l|l|l|}
\hline Tuna, canned water & 0.004 & & & & & Read-across from Plaice & \\
\hline Fish oil & n.a. & & & & & & \\
\hline
\end{tabular}


S6. Mean concentrations of PAH4 in $\mathrm{n} \mathrm{kg}^{-1}$ with sample numbers, positive samples, minimum, maximum concentrations and comments with respective references.

\begin{tabular}{|c|c|c|c|c|c|c|c|}
\hline Seafood & $\begin{array}{c}\text { PAH4 } \\
\left(\text { ng kg }^{-1}\right)\end{array}$ & $\begin{array}{c}\text { No of } \\
\text { samples }\end{array}$ & Positive & $\begin{array}{c}\text { Min. } \\
\left(\mathrm{ng} \mathrm{kg}^{-1}\right)\end{array}$ & $\begin{array}{c}\text { Max. } \\
\left(\mathrm{ng} \mathrm{kg}^{-1}\right)\end{array}$ & Comments & References \\
\hline Cod liver, canned & n.a. & & & & & & \\
\hline Cod roe, canned & n.a. & 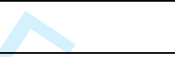 & & & & & \\
\hline Cod, fillet raw & n.a. & + & & & & & \\
\hline Eel, raw & n.a. & & & & & & \\
\hline Eel, smoked & 1820 & 34 & 27 & 0 & 7400 & & $\begin{array}{l}\text { Petersen et al., 2013, } \\
\text { Petersen et al., } 2015\end{array}$ \\
\hline Garfish, raw & 5.9 & 1 & 1 & 0 & 2509 & $\begin{array}{l}\text { Based on one smoked } \\
\text { sample, fat content and } \\
\text { relation smoked/non-smoked } \\
\text { for herring and mackerel }\end{array}$ & $\begin{array}{l}\text { Petersen et al., 2013, } \\
\text { Petersen et al., } 2015\end{array}$ \\
\hline $\begin{array}{l}\text { Greenland halibut, } \\
\text { smoked }\end{array}$ & 130 & 11 & 2 & 0 & 1050 & $\begin{array}{c}\text { Included as others in given } \\
\text { references }\end{array}$ & $\begin{array}{l}\text { Petersen et al., 2013, } \\
\text { Petersen et al., } 2015\end{array}$ \\
\hline Herring, marinated & 20 & & & & 4 & $\begin{array}{l}\text { Read-across from herring, } \\
\text { raw }\end{array}$ & \\
\hline Herring, raw & 20 & 8 & 1 & 0 & 150 & & $\begin{array}{l}\text { Petersen et al., 2013, } \\
\text { Petersen et al., } 2015\end{array}$ \\
\hline $\begin{array}{l}\text { Mackerel, canned in } \\
\text { tomato sauce }\end{array}$ & 61 & & & & & $\begin{array}{c}\text { Read-across from mackerel, } \\
\text { raw }\end{array}$ & \\
\hline Mackerel, raw & 61 & 8 & 1 & 0 & 350 & 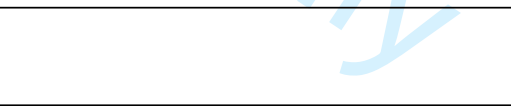 & $\begin{array}{l}\text { Petersen et al., 2013, } \\
\text { Petersen et al., } 2015\end{array}$ \\
\hline Mackerel, smoked & 1540 & 74 & 45 & 0 & 17000 & & $\begin{array}{l}\text { Petersen et al., 2013, } \\
\text { Petersen et al., } 2015\end{array}$ \\
\hline Plaice & n.a. & & & & & & \\
\hline Saithe (UK) fillet & n.a. & & & & & & \\
\hline
\end{tabular}




\begin{tabular}{|l|c|l|l|l|l|l|l|}
\hline Salmon, raw & 20 & & & & & $\begin{array}{c}\text { Read-across from herring, } \\
\text { raw }\end{array}$ & \\
\hline Salmon, smoked & 2450 & 48 & 25 & 0 & 32000 & & $\begin{array}{c}\text { Petersen et al., 2013, } \\
\text { Petersen et al., 2015 }\end{array}$ \\
\hline Shrimps, canned & n.a. & & & & & & \\
\hline Shrimps, frozen & n.a. & & & & & & \\
\hline Trout, Rainbow & n.a. & & & & & & \\
\hline Tuna, canned oil & n.a. & & & & & & \\
\hline Tuna, canned water & n.a. & & & & & & \\
\hline Fish oil & n.a. & & & & & & \\
\hline
\end{tabular}

n.a.: not analysed and no read-across from other fish species has been performed. 